\title{
Analysis of 400 examinations using the gastrocamera
}

\author{
LAURENCE M. BLENDIS, ALAN J. CAMERON, AND GEORGE D. HADLEY
}

From the Middlesex Hospital, London

EDITORIAL COMMENT This study confirms the claim that the use of the gastrocamera is a safe, simple, and easily learnt technique which has been found to be of considerable value in the diagnosis of gastric diseases.

Much interest has recently been shown in the Japanese gastrocamera as a practical alternative to the gastroscope in the diagnosis of gastric disease. More than 50 cameras are in use in Britain at the present time. This instrument has been used in routine clinical investigation in this hospital since August 1963. An analysis of the results obtained in 400 consecutive examinations is presented.

\section{METHODS AND MATERIALS}

The mark V Olympus gastrocamera was used as described by Hadley (1965). Recently we have reduced the premedication for out-patients to an injection of scopolamine and an amethocaine lozenge. Examinations were performed on one morning each week by any one of several operators. The patients were those seen in routine clinical practice with known or suspected gastric lesions. Each developed film was read by at least two observers who were aware of the clinical and barium meal findings. In those patients who did not undergo surgery an unequivocal barium meal or gastrocamera findings were accepted as the correct diagnosis for the purpose of this analysis.

\section{RESULTS}

BENIGN GASTRIC ULCER Table I compares the findings with gastrophotography and with barium meals in 103 patients with gastric ulcer. Sixteen patients were examined on two or more occasions.

TABLE I

COMPARISON OF INVESTIGATIONS OF GASTRIC ULCER

\begin{tabular}{|c|c|c|}
\hline Barium Meal & Gastrocamera & Number of Patients \\
\hline$+\mathrm{ve}$ & $+\mathrm{ve}$ & $59(57.3 \%)$ \\
\hline$+\mathrm{ve}$ & $-\mathrm{ve}$ & $31(30.1 \%)$ \\
\hline- ve & $+\mathrm{ve}$ & $13(12.6 \%)$ \\
\hline & Total & 103 \\
\hline
\end{tabular}

Only the findings on the first examination are included in this analysis. The camera detected the lesion in 72 patients $(70 \%)$ and radiographs showed an ulcer in $91(88.4 \%)$. We have arbitrarily divided the stomach into three parts, as shown in Table II, and compared the results. It will be seen that the likelihood of photographing an ulcer varied according to its site.

\section{TABLE II}

ANALYSIS OF DIAGNOSIS OF GASTRIC ULCER ACCORDING TO SITE

\begin{tabular}{lcc} 
Ulcer Site & $\begin{array}{c}\text { Number of } \\
\text { Patients }\end{array}$ & $\begin{array}{l}\text { Gastrocamera } \\
\text { Positive }\end{array}$ \\
\hline Upper $\frac{1}{8}$ stomach & 24 & $9(37.5 \%)$ \\
Middle $\frac{1}{\text { t, including angulus }}$ & 64 & $54(84 \cdot 5 \%)$ \\
Distal to angulus & 15 & $9(60 \%)$ \\
& Total 103 & $72(70 \%)$
\end{tabular}

BENIGN TUMOURS Eight patients were diagnosed as having benign gastric tumours on gastrophotography. Four of these cases were of multiple polyposis, including two patients with the PeutzJeghers syndrome only one of whom had been shown to have gastric polyps after a barium meal. The other four patients were thought to have single benign gastric tumours. One was a large neurofibroma proven histologically. Another, a large leiomyoma in the upper part of the stomach, was missed despite good views of that region. Two patients were diagnosed as having solitary polyps. However, one of these was shown by further barium meals to be the oedematous edge of a benign ulcer, photographed in profile. In the second patient, laparotomy failed to reveal any abnormality in the stomach.

GASTRIC CARCINOMA Nineteen of 26 primary gastric carcinomas were seen on gastrophotography (Table III). Of the 23 results of barium meals recorded in Table III as showing carcinoma, 16 were diagnostic and in seven the appearances were no more than suspicious. Of these seven patients, six were confirmed on gastrophotography to have carcinoma. In the remaining patient satisfactory 
TABLE III

COMPARISON OF INVESTIGATIONS OF PRIMARY CARCINOMA OF THE STOMACH

\begin{tabular}{ccc}
$\begin{array}{l}\text { Carcinoma Shown } \\
\text { by Barium Meal }\end{array}$ & $\begin{array}{l}\text { Carcinoma Shown } \\
\text { by Gastrocamera }\end{array}$ & Number of Patients \\
\hline$+\mathrm{ve}$ & $+\mathrm{ve}$ & $17(65 \%)$ \\
+ve & $-\mathrm{ve}$ & $6(23 \%)$ \\
- ve & $+\mathrm{ve}$ & $2(7 \cdot 7 \%)$ \\
$-\mathrm{ve}$ & $-\mathrm{ve}$ & $1(3.8 \%)$ \\
& & Total 26
\end{tabular}

photographs were not obtained. However, the camera demonstrated a carcinoma in two cases in which the radiologist did not suspect malignancy. In one of these, the $x$-ray findings had been interpreted as showing a benign ulcer, and, in the other, coarse lesser curve rugae were seen but not considered to be of pathological significance. Finally one patient with negative radiological and camera findings was investigated again a year later and shown to have carcinoma of the fundus, which had almost certainly been present at her first admission.

Forty patients in this series were photographed because the barium meal showed an area of possible malignancy (Table IV). Radiological findings in

TABLE IV

GASTROCAMERA FINDINGS WHERE BARIUM MEAL SHOWED POSSIBLE MALIGNANCY

\begin{tabular}{|c|c|c|c|c|}
\hline Site of Suspicious & Number & Camera & & Number of \\
\hline Meal & Pat & $\begin{array}{l}\text { Adequate } \\
\text { Coverage }\end{array}$ & $\begin{array}{l}\text { Diagnosis } \\
\text { Carcinoma }\end{array}$ & Car \\
\hline
\end{tabular}

\begin{tabular}{|c|c|c|c|c|}
\hline Upper $\frac{1}{3}$ stomach & 11 & 5 & $2^{1}$ & 1 \\
\hline $\begin{array}{l}\text { Middle } \frac{1}{3} \text {, including } \\
\text { angulus }\end{array}$ & 15 & 14 & 4 & $5^{2}$ \\
\hline Distal to angulus & 12 & 10 & 1 & 1 \\
\hline Stoma & 2 & 2 & $2^{1}$ & 1 \\
\hline Total & 40 & 31 & 9 & 8 \\
\hline
\end{tabular}

${ }^{1}$ Includes one false positive diagnosis

${ }^{2}$ Includes one patient with lymphosarcoma

this group included localized areas of abnormal rugae, possible filling defects, and suspicious gastric ulcers. In 31 patients the abnormal area on the radiograph was adequately covered by the camera. Findings in seven of these patients who proved to have a carcinoma are discussed in the preceding paragraph. It will be noted that in two cases a false positive diagnosis of carcinoma was made. One of these patients was shown to have a large benign tumour in the fundus at laparotomy. The other had had a partial gastrectomy and was thought to have a carcinoma at the anastomosis but at operation no tumour was found. In addition, six benign gastric ulcers and two benign gastric tumours were shown by the camera and in the remaining patients no abnormality was seen.
HIATUS HERNIA Fourteen patients with hiatus hernia were examined. Four were known to have an associated gastric ulcer at or above the level of the diaphragm but the camera failed to demonstrate any of these.

DUODENAL ULCER Although the camera was introduced to its full length $(75 \mathrm{~cm}$.) routinely, no views of the duodenum were obtained. Of 18 patients with duodenal ulceration, five were noted to have hypertrophic gastric mucosa.

UPPER GASTROINTESTINAL BLEEDING No attempt was made to use gastrophotography as an emergency procedure because there was always a delay of two to four days before the results were known due to the time taken to develop the films. Twenty-nine patients were examined at the first routine session after their admission to hospital with haematemesis or melaena (Table V). Two patients with negative barium meals were shown to have acute erosions, and in a third case multiple mucosal haemorrhages following salicylate ingestion were seen. Other positive camera findings included seven chronic gastric ulcers and one neurofibroma.

\section{TABLE V}

COMPARISON OF INVESTIGATIONS (GASTRIC LESIONS ONLY) OF HAEMATEMESIS AND MELAENA

\begin{tabular}{ccc} 
Barium Meal & Gastrocamera & Number of Patients \\
\hline +ve & +ve & 7 \\
+ve & $-\mathrm{ve}$ & 3 \\
- ve & +ve & 3
\end{tabular}

THE POST-OPERATIVE STOMACH Gastrophotography was performed on one occasion in each of 33 patients who had undergone gastric surgery in the past. The entire stoma was seen in 10 and part of the stoma in 11 of 26 patients with a partial gastrectomy. No views of the upper part of the gastric remnant were obtained and in only seven of the 26 patients was the lower part covered satisfactorily. The type of partial gastrectomy performed did not affect the results. In some of these cases photography failed because the small size of the gastric remnant left insufficient room to manoeuvre the camera. Difficulty was experienced in judging the distance the instrument needed to be introduced to photograph the stoma since fluoroscopic control was not always available. However, in four out of five patients with a gastroenterostomy, satisfactory views were obtained of the stoma and the rest of the stomach.

The results in cases of stomal ulcers are shown in Table VI. The findings in five patients suspected of malignancy in the gastric remnant on barium meal studies are shown in Table VII. Photography cor- 
TABLE VI

COMPARISON OF INVESTIGATIONS OF STOMAL ULCERS

\begin{tabular}{ccc} 
Barium Meal & Gastrocamera & Number of Patients \\
\hline$+\mathrm{ve}$ & $+\mathrm{ve}$ & 5 \\
$+\mathrm{ve}$ & $-\mathrm{ve}$ & 3 \\
$-\mathrm{ve}$ & $+\mathrm{ve}$ & 0
\end{tabular}

TABLE VII

COMPARISON OF INVESTIGATIONS OF CARCINOMA OF GASTRIC REMNANT

\begin{tabular}{lcc}
$\begin{array}{l}\text { Barium Meal Showing } \\
\text { Possible Carcinoma }\end{array}$ & $\begin{array}{l}\text { Gastrocamera Diagnosis } \\
\text { Carcinoma }\end{array}$ & $\begin{array}{l}\text { Proven } \\
\text { Carcinoma }\end{array}$ \\
\hline 5 & 3 & 2
\end{tabular}

rectly confirmed the diagnosis in two; another was incorrectly interpreted as showing malignant disease (this case has been described in the paragraph on carcinoma) and the remaining two examinations were unsatisfactory.

NEGATIVE BARIUM MEALS In this series there were 117 patients whose barium meals showed no abnormality. In 16 of these gastrophotography demonstrated a lesion as shown in Table VIII. In

\section{TABLE VIII}

LESIONS DETECTED ON GASTROPHOTOGRAPHY AFTER NEGATIVE RADIOGRAPHS IN 117 PATIENTS

$\begin{array}{lr}\text { Benign gastric ulcer } & 13 \\ \text { Multiple polyps } & 2 \\ \text { Malignant invasion of stomach wall } & 1 \\ \text { (by carcinoma of pancreas) } & \end{array}$

six of the 13 patients with gastric ulcer the diagnosis was later confirmed either at operation or on repeat radiographs. The remaining seven patients were inadequately followed up so confirmation of the camera diagnosis was not possible. The patient in whom malignant infiltration was seen on gastrophotography was found at operation to have an invasive carcinoma of the pancreas. In addition one false diagnosis was made. This patient, thought to have a gastric polyp, has already been discussed in the section on benign tumours.

In 101 of the patients with negative barium meals no lesion was demonstrated by gastrophotography, four patients being examined on more than one occasion. Their gastrofilms have been reviewed to assess how adequately the different regions of the stomach were visualized (Table IX). Photography of the fundus and cardia was not routinely attempted in these patients. In $30.2 \%$ all other areas were satisfactorily covered at a single examination.

\section{TABLE IX}

NEGATIVE BARIUM MEALS AND GASTROPHOTOGRAPHS: NUMBER OF EXAMINATIONS WHERE SATISFACTORY COVERAGE WAS OBTAINED BY THE GASTROCAMERA IN VARIOUS REGIONS OF THE STOMACH

\begin{tabular}{lccccc}
$\begin{array}{l}\text { No. of } \\
\text { Examinations }\end{array}$ & Pylorus & Antrum & Angulus & $\begin{array}{l}\text { Lesser } \\
\text { Curve }\end{array}$ & $\begin{array}{l}\text { Greater } \\
\text { Curve }\end{array}$ \\
\hline 106 & 45 & 55 & 87 & 59 & 65
\end{tabular}

THE OPERATORS Most of the examinations were performed by the same five members of the hospital staff but nine others used the camera on one or more occasions. The skill of the operators has been assessed. Table $X$ analyses the efficiency of the different operators in obtaining a photograph of the lesion when a gastric ulcer or neoplasm was present and shows the reasons for failure in this group of cases.

REASONS FOR FAILURE OF EXAMINATION In eight patients during the period under review the camera could not be passed into the stomach. In two, failure was due to lack of cooperation by the patient, in three to structural deformities, and in the other three to presumed spasm of the cardia. Sometimes the stomach could not be adequately distended with air. This was particularly noted after partial gastrectomy, with hour-glass deformity, in cases with diffuse malignant infiltration of the stomach wall, and in a few patients who belched persistently during the examination. In three patients with pyloric stenosis, gastric contents obscured much of the inside of the stomach despite preliminary aspiration. Blood or mucus on the lens sometimes blurred a few frames, but only rarely was an entire

TABLE X

COMPARISON OF EFFECTIVENESS OF DIFFERENT OPERATORS IN PHOTOGRAPHING LESIONS AND REASONS OF FAILURE

\begin{tabular}{|c|c|c|c|c|c|c|c|}
\hline \multirow[t]{2}{*}{ Operator } & \multirow{2}{*}{$\begin{array}{l}\text { Total No. } \\
\text { of Lesions }\end{array}$} & \multirow{2}{*}{$\begin{array}{l}\text { Lesions Shown } \\
\text { by Photography }\end{array}$} & \multicolumn{5}{|c|}{ Unsatisfactory Examinations } \\
\hline & & & $\begin{array}{l}\text { Failure to Pass } \\
\text { Instrument }\end{array}$ & $\begin{array}{l}\text { Insufficient } \\
\text { Air }\end{array}$ & Dirty Lens & Lesion Obscured & $\begin{array}{l}\text { Inadequate } \\
\text { Cover }\end{array}$ \\
\hline 1 & 45 & $35(77 \cdot 8 \%)$ & 2 & 3 & 1 & - & 4 \\
\hline 2 & 32 & $22(68.8 \%)$ & - & 1 & - & 1 & 8 \\
\hline 3 & 30 & $23(76 \cdot 7 \%)$ & - & 1 & - & 1 & 5 \\
\hline 4 & 21 & $18(85.7 \%)$ & - & 1 & - & 1 & 1 \\
\hline 5 & 36 & $26(72.2 \%)$ & 1 & - & 2 & - & 7 \\
\hline Others & 18 & $10(55.5 \%)$ & 1 & 3 & 1 & - & 3 \\
\hline Total & 182 & $134(73.6 \%)$ & 4 & 9 & 4 & 3 & 28 \\
\hline
\end{tabular}


film spoilt. However, the commonest cause of failure to photograph a lesion was that views of the appropriate part of the stomach had not been obtained. This occurred on 28 occasions as shown in Table X.

\section{DISCUSSION}

Although the gastrocamera was first developed in Japan in 1950, it has only been used outside that country in the last few years (Chrysospathis, 1963; Hara, Ogoshi, Karasawa, Osawa, Yodoyama, and Ansfield, 1964; Morrissey, Honda, Hara, Juhl, and Perna, 1965; Milton, Lynch, and Skyring, 1965; Hillman, 1965; Kalokes inos, Hunt, and Pryor, 1965). After three years' experience we have formed certain opinions as to its place in the diagnosis of gastric disease. Radiology remains the most important initial investigation in disorders of the upper gastrointestinal tract, but it often fails to provide sufficient information and additional diagnostic aids are therefore required. In the field of endoscopy the fibrescope and gastrocamera have recently appeared as rivals to the conventional gastroscope. The advantages of the camera over the gastroscope have been discussed previously (Hadley, 1965). Briefly the camera, being thinner and more flexible, is easier to pass, safer and causes less discomfort. The films provide a permanent record which can be discussed by an unlimited number of observers and thus the interpretation of results is readily learnt.

Except when a stomach is pathologically distorted it is theoretically possible to cover every part of it with the gastrocamera. By looping the distal end of the instrument it is possible to photograph the fundus and cardia, a region normally inaccessible to the gastroscope, although Edwards and Muggia (1965) have described a similar technique which they employed with the fibrescope. However, full coverage is not often obtained because of inexperience or insufficient care on the part of the operator, variability in the shape of the stomach, or blurring of the lens by mucus.

\section{TABLE XI}

COMPARISONS OF INVESTIGATIONS BY PREVIOUS AUTHORS OF GASTRIC ULCER

\begin{tabular}{lccc} 
Author & $\begin{array}{l}\text { Gastrocamera } \\
\text { Positive }\end{array}$ & $\begin{array}{l}\text { Gastroscopy } \\
\text { Positive }\end{array}$ & $\begin{array}{l}\text { Radiographs } \\
\text { Positive }\end{array}$ \\
\hline Morrissey et al. (1965) & $74 \%$ & $58 \%$ & $66 \%$ \\
Milton et al. $(1965)$ & $82 \%$ & $74 \%$ & $96 \%$
\end{tabular}

Morrissey et al. (1965) and Milton et al. (1965) found that gastric ulcers were seen more frequently on gastrophotography than on gastroscopy (Table
XI). Milton et al. (1965) also investigated cases of gastric carcinoma and noted that the lesion was detected more often by the gastrocamera than by the gastroscope or fibrescope. Perna, Honda, and Morrissey (1965) reviewed Japanese papers comparing the results of radiology and gastrophotography in the investigation of gastric ulcer and carcinoma; in both conditions the camera was found to achieve slightly better results, whereas in our series we have found the reverse (Tables I and III). However, a combination of these two investigations demonstrated considerably more lesions than either method alone.

One in 10 of the patients in this series was investigated because a barium meal showed an abnormality suggestive but not diagnostic of malignancy. In this situation the gastrocamera proved of great value, since in most cases satisfactory views of the appropriate area of the stomach were obtained and a correct diagnosis was made (Table IV). In the whole series a correct camera diagnosis was made in $73.2 \%$ of cases of primary gastric carcinoma. This compares with $92.9 \%$ (Chrysospathis, 1963), $88.9 \%$ (Milton et al., 1965) and 77 to $96 \%$ in earlier Japanese series as quoted by Perna et al. (1965). The camera also proved helpful in establishing the nature of some large benign tumours but difficulty was encountered in differentiating small, solitary polyps from unusually shaped mucosal folds.

We feel that we should increase our diagnostic accuracy with further experience which remains small compared with that of our Japanese colleagues. Had the number of operators in this series been strictly limited, our results might have been better. Although our instrument (mark V) is the one most commonly used in Japan, at least two other models are available. One, a combined camera and fibrescope, increases the chances of photographing a lesion whereas the second is specially designed to photograph fundal lesions and to obtain better results in post-gastrectomy patients. Finances permitting, the possession of all three cameras would undoubtedly produce better results.

\section{SUMMARY}

Gastrophotography is a safe, simple, and easily learnt technique, which has been found to be of considerable value in the diagnosis of gastric lesions. It is essentially complementary to radiology. It is particularly helpful in patients suspected of malignant disease and in patients with radiologically negative dyspepsia. Reasons for failure have been analysed and methods of improving the results discussed. 
We should like to thank our colleagues, Dr. Peter Spence and Mr. Jeremy Wilson, for performing some of the gastrocamera examinations and Sisters Margaret Holmes, Ann Bealey, and their staff for assisting at the examinations.

\section{REFERENCES}

Chrysospathis, P. (1963). Gastric camera: additional tool to improve diagnostic accuracy for lesions of the stomach. Surgery, 54, 292-295.

Edwards, T. L., Jr., and Muggia, A. L.(1965). Examination of the gastric fundus with the fibergastroscope. Report of a new technic. Amer. J. dig. Dis., 10, 936-938.
Hadley, G. D. (1965). The gastro-camera. Brit. med. J., 2, 1209-1212, Hara, Y., Ogoshi, K., Karasawa, K., Osawa, G., Yokoyama, Y., and Ansfield, F. J. (1964). Clinical experience with the gastrocamera. Ann. Surg., 159, 542-547.

Hillman, H. S. (1965). Gastrophotography. Med. J. Aust., 1, 618-619.

Kalokerinos, J., Hunt, J., and Pryor, A. W. (1965). The gastrocamera. Its use, value, and recent developments. J. Coll. Radiol. Aust., 9, 52-58.

Milton, G. W., Lynch, A., and Skyring, A. P. (1965). The diagnosis of gastric lesions. An assessment of the role of the gastro-camera. Brit. J. Surg., 52, 607-612.

Morrissey, J. F., Honda, T., Hara, Y., Juhl, J. H., and Perna. G. (1965). The use of the gastrocamera for the diagnosis of gastric ulcer. Gastroenterology, 48, 711-717.

Perna, G., Honda, T., and Morrissey, J. F. (1965). Gastrocamera photography. Arch. intern. med., 116, 434-441.

\section{The December 1966 Issue}

\section{THE DECEMBER 1966 ISSUE CONTAINS THE FOLLOWING PAPERS}

Coeliac thoughts BRIAN CREAMER

Carcinoma, villous atrophy, and steatorrhoea A. BRZECHWA-AJDUKIEWICZ, C. F. MCCARTHY, W. AUSTAD, J. CORNS, W. J. HARRISON, and A. E. A. READ

Vitamin E levels after gastric surgery P. J. LEONARD, M. S. LOSOWSKY, and C. N. PULVERTAFT

Intestinal colic caused by food FREDERICK O. STEPHENS Calculous disease of the vermiform appendix G. B. FORBES and R. W. LLOYD-DAVIES

Kinetic studies of the epithelial cells of the rectal mucosa in normal subjects and patients with ulcerative colitis ROY G. SHORTER, ROBERT J. SPENCER, and GEORGE A. HALLENBECK

Urinary gonadotrophin excretion in patients with ulcerative colitis and Crohn's disease treated with A. C. T. H. and corticosteroids G. P. CREAN, J. A. LORAINE, E. T. BELL, W. I. CARD, and W. SIRCUS

Emergency surgery in ulcerative colitis T. A. BOXALL

Effects of oestrogens and progestogens on gastric secretion in patients with duodenal ulcer S. P. PARBHOO and I. D. A. JOHNSTON

Gastric acid secretion in Indians with particular reference to the ratio of basal to maximal acid output R. K. GOYAL, P. S. GUPTA, and H. K. CHUTTANI

Histochemical study of the effect of enzyme inhibitors on gastric secretion G. L. STOFFELS, W. GEPTS, and J. J. DESNEUX

Gastrointestinal urease in man

Part I Activity of mucosal urease TOSHIO AOYAGI, GEORGE W. ENGSTROM, WILLIAM B. EVANS, and WILLIAM H. J. SUMMERSKILL

Part II Urea hydrolysis and ammonia absorption in upper and lower gut lumen and the effect of neomycin WILLIAM B. EVANS, TOSHIO AOYAGI, and WILLIAM H. J. SUMMERSKILL
Tetracycline fluorescence and cytological procedures compared for the detection of malignancy L. J. SANDLOW and $H$. NECHELES with the technical assistance of H. LEVERETTE

An electron microscopic study of the epithelium of normal human sigmoid colonic mucosa FRED E. PITTMAN and JOAN C. PITTMAN

Pathology of an East African megacolon G. М. вӧнм and BARBARA SMITH

Recurrent gastric carcinoma treated by the Geiger probe technique D. J. MARTIN

Bowel muscle in diverticular disease w. W. SLACK

Clinical and radiological study of vagotomy and gastric drainage in the treatment of pyloric stenosis due to duodenal ulceration HAROLD ELLIS, F. STORER, C. VENABLES, and C. WARE

Late results of antrectomy and vagotomy ALAN C. B. DEAN, HAROLD C. EDWARDS, AND A. I. MUNRO

ABO blood groups in gastric bleeding L. HORWICH, D. A. P. EVANS, R. B. MCCONNELL, and W. T. A. DONOHOE

Action of aldosterone upon the intestinal transport of potassium, sodium and water R. SHIELDS, ADELE T. MULHOLLAND, and R. G. ELMSLIE

Blocking by spironolactone (SC 9420) of the action of aldosterone upon the intestinal transport of potassium, sodium, and water R.G. ELMSLIE, ADELE T. MULHOLLAND, and $R$. SHIELDS

Radiotelemetering studies of jejunal $\mathrm{pH}$ before and after vagotomy and gastro-enterostomy W. C. WATSON, J. K. WATT, E. PATON, A. GLEN, and G. J. T. LEWIS

International symposium on bile pigments The British Society of Gastroenterology Index

Contents

Copies are still available and may be obtained from the PUBLISHING MANAGER, BRITISH MEDICAL ASSOCIATION, TAVISTOCK SQUARE W.C.I., price 18s. 6D. 